\title{
OVERWEIGHT AND OBESITY AMONG MIDDLE SCHOOL STUDENTS FROM LUBARTÓW INCLUDING NUTRITION AND PHYSICAL ACTIVITY
}

\author{
Diana Piaszczyk ${ }^{1}$, Anna Ławnik ${ }^{1}$, Jolanta Abramczyk ${ }^{2}$
}

\author{
${ }^{1}$ Pope John Paul II State School of Higher Education in Biała Podlaska \\ ${ }^{2}$ Independent Public Healthcare Centre in Lubartów, Pediatric Ward
}

Piaszczyk D., Ławnik A., Abramczyk J. (2014) Overweight and obesity among middle school students from Lubartów including nutrition and physical activity, Health Problems of Civilization 1 (VIII), p. 45-54

Summary: The percentage of children and adolescents with overweight and obesity problem is higher in Poland than in other European countries, and for this reason, this group ought to be covered by educational actions in order for them to cause changes in their current lifestyle.

The aim of the study was to present the scale of overweight and obesity, and knowledge of the principles of nutrition, dietary behaviors and physical activity in daily life of middle school students from Lubartów. The study was conducted on a group of 100 Lubartów students in grades I-III, aged 13-15 years. The applied method of research was diagnostic survey and authorial interview questionnaire was the main tool. $11.3 \%$ of researched girls were found to be overweight and obesity was confirmed for $7.5 \%$ of all respondents. Most overweight boys and boys with obesity were 15 years of age. Respondents declared knowledge of the principles of nutrition, more frequently girls with abnormal body weight than boys. Youngsters tend to eat what they like, while they rarely draw attention to the fact whether the product is healthy. Five meals a day were consumed by a total of $30 \%$ of students and $44.0 \%$ of the students always ate breakfast. It has been shown that $59.1 \%$ of adolescents with abnormal body weight were dissatisfied with their performance. Based on the results the following conclusions were drawn up:

1. Obesity occurs in $7.50 \%$ of girls and $8.50 \%$ of boys of the middle school in Lubartów.

2. Youth knows the principles of nutrition, but does not always select the healthy products, eats inappropriately, eats snacks between meals.

3. Middle school students rarely eat vegetables, fruits and dairy products.

4. Hereditary phenomenon of obesity was observed in subjects with abnormal body weight.

5. Youth is not physically active, they spend their free time in a passive way.

6. Overweight / obesity determine a negative social assessment by peers.

\section{Introduction}

Overweight and obesity is a serious public health problem, referred to as an epidemic, concerning each age group, creating a threat that it might survive to adulthood and cause cardiovascular disease, diabetes type II, cancers, diseases of the osteoarticular system, emotional disorders (Mazur 2011).

Pro-health behaviors emerging at the stage of school education have a significant impact on health in the future. An important element of health education is to develop the right habits and promote daily physical activity (Smorczewska-Czupryńska et al., 2004).

Overweight according to Oblacińska is an excess of body weight in relation to height, caused by a long-term positive energy balance and low physical activity (Oblacińska et al., 2007). Obesity is a metabolic disease manifested by an increase of body fat, resulting from the imbalance between energy intake and energy expenditure (Oblacińska et al., 2007).

Depending on the distribution of adipose tissue four types of obesity are distinguished. First, general obesity, in which excess body fat is distributed evenly. In the android (apple) form the fat accumulates in the upper body and in the visceral (abdominal) part is localized in the abdomen. The last type of obesity called by researchers genocidal, „pear”, is associated with the area of accumulation of fat on the hips, buttocks, thighs, and affects female (Dolżał-Ołtarzewska, Starzyk 2005). In the literature, it is noted that the type II and III obesity, typical for men, increases the risk of metabolic disorders, hypertension, diabetes and cardiovascular disease (Dolżał-Ołtarzewska, Starzyk 2005).

Due to the causes of obesity, we can distinguish the primary (simple) and secondary obesity. In the primary form, environmental factors and genetic factors are important, but it is always a prerequisite for there to occur a long-lasting, positive energy balance (Jarosz 2010). This phenomenon refers to the excessive consumption of foods

Adres do korespondencji: Diana Piaszczyk, Pope John Paul II State School of Higher Education in Biała Podlaska, ul. Sidorska 95/97, 21-500 Biała Podlaska e-mail: dianaj23@tlen.pl, phone: +48 (83) 344-99-18 
rich in animal fats and simple carbohydrates and a limited physical activity. It is observed in $40-70 \%$ of children and adolescents and it is associated with a sedentary lifestyle and the presence on the market of unhealthy food (Plewa, Markiewicz 2006).

Research conducted up to date on the subject indicate a genetic basis, since the body weight is inherited according to the rules concerning the transfer of operations of multigene systems regulating the metabolic activity of adipose tissue, the sensitivity level of the central nervous system towards leptin. Hereditary tendency of obesity constitutes tendencies stemming from the construction of the body, improper storage of fat, slow metabolism and thermoregulation (Oblacińska et al., 2006).

It is found that overweight and obesity are adverse to the health and economic point of view, and the previous studies show that the cost of health care for obese people is about $44 \%$ higher than in subjects with normal body weight. In addition, individuals with a BMI> 30 live shorter, and the risk of premature death is with them about $50-100 \%$ higher than in subjects with normal BMI (Oblacińska et al., 2006).

It is observed that as the cases of overweight or obesity intensify, pathologies and dysfunctions appear, for all systems and organs, such as changes in overload of the osteoarticular system (pain, swelling, distortion, flat feet, scoliosis), mental changes (depression, neurosis ) (Gałuszka, Gałuszka 2010).

It is observed that obesity in children and adolescents affects health in adulthood, because with age the risk of obesity-related diseases increases. Lipid disorders and hypertension leading to myocardial infarction, heart failure, stroke, left ventricular hypertrophy, cancer (breast, colon, prostate, kidney, gallbladder). These changes contribute to the development of type II diabetes, degenerative diseases of the spine and lower limbs (Gawlik et al., 2009, Kochman, Karaś 2011, Krebs, Primak 2012).

On the basis of the literature it is stated that you can not clearly define the extent of the problem of overweight and obesity in Poland, but only observe that this percentage increases in the various regions of the country, however, an objective presentation of national data encounters difficulties related to the lack of uniform criteria for the assessment of nutritional status of the test performing individuals.

Due to the fact that the BMI in children and adolescents varies with height increase, research on the measurement of body weight uses tables or centile charts that take into account gender and age of the respondents (Jodłowska 2007, Oblacińska et al., 2007). Nutritional status of the organism is evaluated on the basis of BMI determining the weight to height ratio, the so called weight-growth rate. In children and adolescents, BMI varies with age, therefore, to assess the degree of overweight and obesity in children and adolescents a grid or centile tables for BMI indicator for age and gender are used (Jodłowska et al., 2007).

In view of the literature it is stated that to assess the degree of obesity measure of waist circumference navel is used, the so called WC (Waist Circumference), waist-to-hip ratio, the so-called. WHR (Waist Hip Ratio) and the ratio of waist circumference to height of the body, ie, WHtR (Waist to Height Ratio). Skinfold thickness is less often used through the use of skinfoldmeter [20]. Other diagnostic methods that allow to recognize obesity and body fat distribution in organs are retroperitoneal imaging MRI, CT, bioelectrical impedance analysis (BIA), the X-ray absorptiometry of the two energies (DEXA) (Jodłowska i et al., 2007).

When considering the problem of prevention of overweight and obesity it must be noted that reasonable feeding of the children and adolescents is a complex process as the need for energy can not be clearly defined, as every person grows individually and hence the differences in energy demand according to gender, but excess of calories at this age is the cause of overweight and obesity. It is found that the intervals between meals should not exceed 3-4 hours, since longer breaks cause a habit of snacking. The correct menu should contain 5 meals, of which at least 3 meals should contain whole grain. Vegetables should be spread over 3-5 servings, and fruits- 2-4, as they provide vitamins, minerals and fiber. According to the researchers the right amount of protein and calcium will be provided by 3-4 servings of milk, two servings of fish, poultry, legumes, lean meat, and nuts. It is stated that fats should constitute only a food additive. Important role in proper nutrition is played by water, the necessary intake of which equates to $2200-3000 \mathrm{ml} /$ day depending on gender and age. The salt in the diet should be limited to $5 \mathrm{~g}$ per day, since excess increases the risk of cardiovascular disease and hypertension (Jarosz 2010).

According to WHO recommendations, children and adolescents should devote to physical activity at least 60 minutes a day and exceeding the recommended minimum exercise time promotes the prevention of overweight and obesity (Jarosz 2010).

The problem of overweight and obesity is a public health priority, because the costs associated with the treatment of obesity and its consequences are disproportionate to the preventive measures (Jarosz 2010, Krajewska-Siuda et al. 2009). A special role in the prevention of overweight and obesity in children and adolescents is served by a nurse, and knowledge possessed by her allows for early identification of a student with excess body weight, thanks to screening tests. 
Activities of health education coordinator in schools rely on providing students information about healthy lifestyles, the role of movement and knowledge on the effects of overweight and obesity, which become the motivation to change negative habits (Jodłowska et al., 2007). Health education coordinator carries out health education in schools within individual subjects, agrees implemented educational programs, interacts with the school nurse, school counselor and school organizations offering educational programs and preventive programs, organizes and conducts internal training of teachers and training for others (Jodłowska et al., 2007).

\section{Target of the research}

The aim of the study was to show the extent of overweight and obesity, and knowledge of the principles of nutrition, dietary behaviors and physical activity of daily life of high school students from Lubartow.

\section{Materials and methods}

The study was conducted in the Henryk Sienkiewicz Middle School No. 2. in Lubartów in October 2012, on a group of 100 students of classes I to III. The study used BMI indicator, which is calculated based on weight and height of the subjects. For each tested pupil, the positioning percentile BMI using growth charts was identified having considered their age and gender. It was assumed that BMI equal to or greater than the 85 percentile and less than 95 percentile for age and sex indicates overweight, while a value equal to or greater than the 95th percentile is obesity (Oblacińska and others., 2007).

The method of research was a diagnostic survey while the research tool was author's interview questionnaire. The first part of the questionnaire related to age, weight, height, place of residence of the respondents. The second one consisted of 24 questions about diet, leisure time, physical activity, self-perception and obese peers in the school environment. The questionnaire was anonymous. The results were analyzed, percentage rates calculated, tables of test results compiled.

The study involved 100 students aged 13-15 years. The largest group consisted of children at the age of 15 years (55 students). This age range consisted of mostly boys (29\%) than girls (26\%). At the age of 13 years there were less boys (7\%) than girls (15\%). Similar size groups of subjects aged 14 years among girls and boys (respectively $12 \%, 11 \%$ ) were noted. Nutritional status of respondents was rated on the basis of measurements of height and weight. The degree of obesity was based on BMI growth charts and body mass index of boys and girls.

\section{Research results}

It was shown, that there was the same group of girls and boys (4 persons in each group) with a score above 95 percentile. The largest group consisted of subjects whose score ranged from 5 to 85 percentile, but it included more girls (43.0\%) than boys (35.0\%). Numbers of respondents whose nutritional status was in the range of 85 95 percentile was similar (girls 6.0\%, boys 8.0\%) (Table 1). Among girls overweight problem was found in $11.3 \%$ and obesity in $7.5 \%$ of all respondents, more often in girls at the age of $14(5.67 \%)$ and over five times more than among girls at the age of 15 (1.88\%). Obesity, almost twice as often was demonstrated in girls of fifteen (7.5\%) than of 14 year old (3.77\%). There was no evidence of obesity or overweight in girls at the age of 13 years old. Normal weight was most frequently demonstrated in girls of 15 years old (39.6\%) than in the 13 years old (28.3\%) and 14 years old (13.20\%). It was shown that most of the boys were overweight or obese at the age of 15 years old (respectively $10.63 \%$ and $4.25 \%$ ). The same shares were noted among 14 year old overweight and obese boys ( $4.25 \%$ each). Obesity was found in $2.12 \%$ of boys and normal weight was found in $40.82 \%$ of boys of 15 years of age, and similar percentage shares concerned the 13 and 14 year old (respectively 12.7\%, 14.9\%) (Table 2) .

According to the obtained results of the study it was showed that $85 \%$ of respondents lived in the city and $15 \%$ in rural areas. Girls were twice as likely to be living in rural areas (10 people) than boys (5 persons).Similar percentage share were shown among subjects with normal and excessive body mass, living in rural areas (respectively $26.70 \%, 21.20 \%$ ) or urban areas (respectively $73.30 \%, 78.80 \%$ ), thus overweight and obesity does not depend on the place of residence. 
Table 1. Level of nutrition of the researched-total recipients according to gender

\begin{tabular}{|c|c|c|c|}
\hline Level of nutrition of the researched & $\mathbf{5 - 8 5}$ centile & $\mathbf{8 5 - 9 5}$ centile & 95 centile and higher \\
\hline girls & $43,0 \%$ & $6,0 \%$ & $4,0 \%$ \\
\hline boys & 35 & 8 & 4 \\
\hline total & 78 & 14 & 8 \\
\hline
\end{tabular}

Table 2. Overweight, obesity and correct body weight-total researched according to gender and age

\begin{tabular}{|c|c|c|c|c|c|c|c|}
\hline & $\begin{array}{c}\text { girls } \\
\text { at the age } \\
\text { of 13 }\end{array}$ & $\begin{array}{c}\text { girls } \\
\text { at the age } \\
\text { of 14 }\end{array}$ & $\begin{array}{c}\text { girls } \\
\text { at the age } \\
\text { of 15 }\end{array}$ & $\begin{array}{c}\text { boys } \\
\text { at the age } \\
\text { of 13 }\end{array}$ & $\begin{array}{c}\text { boys } \\
\text { at the age } \\
\text { of 14 }\end{array}$ & $\begin{array}{c}\text { boys } \\
\text { at the age } \\
\text { of 15 }\end{array}$ & $\begin{array}{c}\text { All } \\
\text { overweight }\end{array}$ \\
\hline $0,0 \%$ & $3,77 \%$ & $7,50 \%$ & $2,12 \%$ & $4,25 \%$ & $10,63 \%$ & $14,0 \%$ \\
\hline obesity & $0,0 \%$ & $5,67 \%$ & $1,88 \%$ & $0,0 \%$ & $4,25 \%$ & $4,25 \%$ & $8,0 \%$ \\
\hline $\begin{array}{c}\text { correct } \\
\text { body weight }\end{array}$ & $28,30 \%$ & $13,20 \%$ & $39,68 \%$ & $12,78 \%$ & 14,90 & $40,82 \%$ & $78,0 \%$ \\
\hline
\end{tabular}

Respondents declared a general knowledge of the principles of nutrition, (58.2\%, 54.3\%), but more often it were the girls with abnormal body weight than boys (40.0\%, 33.3\%). A good knowledge of the principles of rational nutrition was declared by $46.0 \%$ of boys and $39.5 \%$ girls with normal body weight. In comparison, in case of the tested pupils with abnormal body weight, a good knowledge of the rules was admitted by boys (66.7\%) than girls (50\%). Only $2.3 \%$ of girls with normal body weight and., $10 \%$ of those with excess body weight did not know the rules of proper nutrition.

Eating habits of the respondents were analyzed. Students were asked if they paid attention to healthy products and whether they could select them from the list. The results of boys and girls with normal body weight and excess body weight were analyzed separately. In both groups, it was found that young people ate what they liked, rarely drawing attention to the fact that the product was healthy or not (Table 3). Respondents chose from a list of products those that are healthy according to them. The youth correctly pointed to dark bread, vegetables and cheese as healthy products, but they also considered as healthy an orange juice, which due to the high sugar content is not a healthy product (Table 4).

Table 3. Eating habits-total recipients according to body weight and gender

\begin{tabular}{|c|c|c|c|c|c|}
\hline & $\begin{array}{c}\text { Girls with proper } \\
\text { body weight }\end{array}$ & $\begin{array}{c}\text { Boys with proper } \\
\text { body weight }\end{array}$ & $\begin{array}{c}\text { Girls with excess } \\
\text { body weight }\end{array}$ & $\begin{array}{c}\text { Boys with excess } \\
\text { body weight }\end{array}$ & Total \\
\hline $\begin{array}{c}\text { Chosen food } \\
\text { products }\end{array}$ & $32,6 \%$ & $11,40 \%$ & $25,0 \%$ & $30,0 \%$ & $24,0 \%$ \\
\hline $\begin{array}{c}\text { I eat } \\
\text { what I like }\end{array}$ & $62,80 \%$ & $80,0 \%$ & $58,30 \%$ & $50,0 \%$ & $67,0 \%$ \\
\hline $\begin{array}{c}\text { I don't pay } \\
\text { attention }\end{array}$ & $4,70 \%$ & $8,60 \%$ & $16,70 \%$ & $20,0 \%$ & $9,0 \%$ \\
\hline
\end{tabular}

Table 4. „Healthy” food products in the opinion of the researched-all recipients

\begin{tabular}{|c|c|c|c|c|c|c|c|}
\hline & Wholemeal bread & White bread & Cheese & Orange juice & Sausage & Vegetables & Fries \\
\hline $\begin{array}{c}\text { Girls with } \\
\text { proper body } \\
\text { weight }\end{array}$ & $88,0 \%$ & $10,0 \%$ & $50,0 \%$ & $70,0 \%$ & $10,0 \%$ & $70,0 \%$ & $10,0 \%$ \\
\hline $\begin{array}{c}\text { Boys with } \\
\text { proper body } \\
\text { weight }\end{array}$ & $77,10 \%$ & $31,40 \%$ & $74,30 \%$ & $88,6 \%$ & $8,60 \%$ & $88,60 \%$ & $5,90 \%$ \\
\hline $\begin{array}{c}\text { Boys with } \\
\text { excess body } \\
\text { weight }\end{array}$ & $58,30 \%$ & $0,0 \%$ & $50,0 \%$ & $100,0 \%$ & $8,30 \%$ & $83,0 \%$ & $8,30 \%$ \\
\hline $\begin{array}{c}\text { Girls with } \\
\text { excess body } \\
\text { weight }\end{array}$ & $90,00 \%$ & $10,0 \%$ & $50,0 \%$ & $70,0 \%$ & $10,0 \%$ & $70,0 \%$ & $10,0 \%$ \\
\hline
\end{tabular}


It was shown that 5 meals are eaten by a total of $30 \%$ of the students, more often by girls with excess body weight (50\%) than boys (16.6\%). It was shown that 2-3 meals a day are more often consumed by boys with excessive body weight (30\%) than with normal weight (8.6\%). It was shown that boys with excessive body weight ate 4 meals a day five times more often than girls, respectively (50\%, 10\%). Among those who consumed more than 5 meals a day, these were more likely boys of normal weight (22.9\%) than boys with excessive body weight (8.3\%) (Table 5).

Table 5. Number of consumed meals during the day-total researched according to gender and body weight

\begin{tabular}{|c|c|c|c|c|}
\hline & $\mathbf{2 - 3}$ meals & $\mathbf{4}$ meals & $\mathbf{5}$ meals & More than 5 meals \\
\hline Girls with proper body weight & $27,90 \%$ & $27,90 \%$ & $30,20 \%$ & $13,00 \%$ \\
\hline Boys with proper body weight & $8,60 \%$ & $40,0 \%$ & $28,60 \%$ & $22,90 \%$ \\
\hline Boys with excess body weight & $25,0 \%$ & $10,0 \%$ & $50,0 \%$ & $10,0 \%$ \\
\hline Girls with excess body weight & $30,0 \%$ & $50,0 \%$ & $16,60 \%$ & $8,30 \%$ \\
\hline Total & $21,0 \%$ & $33,0 \%$ & $30,0 \%$ & $16,0 \%$ \\
\hline
\end{tabular}

Based on the results of the research included in Table 6 it was demonstrated that $44.0 \%$ of students always eat breakfast, but up to $42.0 \%$ of all respondents answered that it so happens that they do not eat breakfast. It was observed that young people with excess body weight more often „do not eat breakfast at all” than those with normal body weight. It was shown that boys with normal body weight „always” eat breakfast (48.6\%). The respondents were also asked what they most commonly consumed for lunch during the break (Table 7).

Table 6. Eating breakfast-total researched according to gender and body weight

\begin{tabular}{|c|c|c|c|}
\hline & I always eat breakfast & I don't eat breakfast & It happens that I don't eat breakfast \\
\hline Girls with proper body weight & $42,0 \%$ & $14,0 \%$ & $44,0 \%$ \\
\hline Boys with proper body weight & $48,60 \%$ & $11,40 \%$ & $40,0 \%$ \\
\hline Boys with excess body weight & $40,0 \%$ & $20,0 \%$ & $40,0 \%$ \\
\hline Girls with excess body weight & $41,60 \%$ & $16,60 \%$ & $41,60 \%$ \\
\hline Total & $44,0 \%$ & $14,0 \%$ & $42,0 \%$ \\
\hline
\end{tabular}

Table 7. Food products consumed at 2nd breakfast-total researched according to gender and body weight

\begin{tabular}{|c|c|c|c|c|c|}
\hline & Sandwich & Fruit & I don't eat 2nd breakfast & Yeast cake & Crisps \\
\hline Girls with proper body weight & $48,80 \%$ & $23,20 \%$ & $20,90 \%$ & $30,20 \%$ & $2,30 \%$ \\
\hline Boys with proper body weight & $25,70 \%$ & $5,70 \%$ & $40,0 \%$ & $28,60 \%$ & $2,90 \%$ \\
\hline Boys with excess body weight & $30,0 \%$ & $0,0 \%$ & $40,0 \%$ & $10,0 \%$ & $20,0 \%$ \\
\hline Girls with excess body weight & $58,30 \%$ & $8,30 \%$ & $25,0 \%$ & $16,60 \%$ & $8,30 \%$ \\
\hline Total & $40,0 \%$ & $13,0 \%$ & $30,0 \%$ & $26,0 \%$ & $5,0 \%$ \\
\hline
\end{tabular}

It was shown that pupils consumed sandwiches for the second breakfast $(40.0 \%)$ or bun (26.0\%). Fruits were eaten by boys with normal weight for their second breakfast five times less often (5.7\%) than by girls (23.2\%), and only by $8.3 \%$ of boys with excess body weight. It was found that $30 \%$ of students did not eat their second breakfast at school and $20 \%$ of girls with excess body weight ate chips for second breakfast.

It was shown that $40 \%$ of boys with normal weight, drew attention to the regularity of meals, but this was more seldom among girls (23.2\%). It was observed that almost $1 / 2$ of boys with excessive body weight did not pay attention to the regular nutrition and up to $50.0 \%$ consumed meals at different times (Table 8). The answer to the question „do you snack between meals" was by $42.9 \%$ of boys and $48.8 \%$ of girls of normal weight given as positive, admitting that they do it often. Similar percentage groups of boys and girls with normal body weight ate between meals rarely, respectively (51.4\%, 48.8\%). Not snacking between meals was more often declared by girls with excessive weight (Table 9) 
Table 8. Regularity of eating-total of researched according to gender and body weight

\begin{tabular}{|c|c|c|c|}
\hline & $\begin{array}{c}\text { Yes, } \\
\text { I try to eat regularly }\end{array}$ & $\begin{array}{c}\text { I don't } \\
\text { pay attention to when I eat }\end{array}$ & $\begin{array}{c}\text { I don't } \\
\text { eat at various times }\end{array}$ \\
\hline Girls with proper body weight & $23,20 \%$ & $39,50 \%$ & $37,20 \%$ \\
\hline Boys with proper body weight & $40,0 \%$ & $45,70 \%$ & $14,30 \%$ \\
\hline Boys with excess body weight & $0,0 \%$ & $50,0 \%$ & $50,0 \%$ \\
\hline Girls with excess body weight & $33,30 \%$ & $33,30 \%$ & $33,30 \%$ \\
\hline Total & $28,0 \%$ & $42,0 \%$ & $30,0 \%$ \\
\hline
\end{tabular}

Table 9. Snacking between meals-total researched according to gender and body weight

\begin{tabular}{|c|c|c|c|}
\hline & Yes, often & It happens but rarely & I don't snack \\
\hline Girls with proper body weight & $48,80 \%$ & $48,80 \%$ & $2,30 \%$ \\
\hline Boys with proper body weight & $42,90 \%$ & $51,40 \%$ & $5,70 \%$ \\
\hline Boys with excess body weight & $50,0 \%$ & $40,0 \%$ & $10,0 \%$ \\
\hline Girls with excess body weight & $50,0 \%$ & $41,60 \%$ & $5,70 \%$ \\
\hline Total & $37,0 \%$ & $48,0 \%$ & $5,0 \%$ \\
\hline
\end{tabular}

The questionnaire questions concerned the preferred beverage of pupils. It was observed that boys with normal body weight frequently drank tea (62.9\%) and girls - juices (58.10\%). Girls with excessive weight indicated juices and mineral water (40\%) and boys pointed to the tea (58.3\%) (Table 10$)$.

The results of the research show that $11.6 \%$ of girls with normal weight and $30 \%$ of girls with excess body weight did not eat dairy products. It was shown that $45.7 \%$ of boys with normal weight and $50 \%$ of boys with excess body weight consumed products in the group once a day. $62.8 \%$ of girls of normal weight declared consuming milk several times a week (Table 11).

Table 10. Beverages in youth's diet-total researched according to gender and body weight

\begin{tabular}{|c|c|c|c|c|}
\hline & Juices & Carbonated drinks & Mineral water & Tea \\
\hline Girls with proper body weight & $58,10 \%$ & $18,60 \%$ & $55,80 \%$ & $48,80 \%$ \\
\hline Boys with proper body weight & $51,40 \%$ & $48,60 \%$ & $37,10 \%$ & $62,90 \%$ \\
\hline Boys with excess body weight & $40,0 \%$ & $30,0 \%$ & $40,0 \%$ & $20,0 \%$ \\
\hline Girls with excess body weight & $41,60 \%$ & $41,60 \%$ & $50,0 \%$ & $58,30 \%$ \\
\hline Total & $52,0 \%$ & $33,0 \%$ & $47,0 \%$ & $52,0 \%$ \\
\hline
\end{tabular}

Table 11. Frequency of eating dairy products-total researched according to gender and body weight

\begin{tabular}{|c|c|c|c|}
\hline & Once a day & Several times a day & I don't eat them \\
\hline Girls with proper body weight & $25,90 \%$ & $62,80 \%$ & $11,60 \%$ \\
\hline Boys with proper body weight & $45,70 \%$ & $51,40 \%$ & $2,90 \%$ \\
\hline Boys with excess body weight & $30,0 \%$ & $40,0 \%$ & $30,0 \%$ \\
\hline Girls with excess body weight & $50,0 \%$ & $41,60 \%$ & $8,40 \%$ \\
\hline Total & $36,0 \%$ & $54,0 \%$ & $10,0 \%$ \\
\hline
\end{tabular}

All respondents were asked the question about the frequency of consumption of fruits and vegetables. The analysis of the data shows that slightly more than $1 / 2$ of the respondents (54\%) ate them every day, and $43 \%$ of those surveyed consumed them several times a week. Only 3\% of respondents admitted that they do not eat any fruit and vegetables. It was observed that boys of normal weight (60\%) more often than girls (48.8\%) consumed fruits and vegetables daily. The girls of normal weight (48.8\%) more frequently than those with excessive weight $(40 \%)$ consumed fruits and vegetables several times a week, while $10 \%$ of girls with excess body weight did not consume any fruit and vegetables (Table 12). 
Table 12. Frequency of eating vegetables and fruits-total researched according to gender and body weight

\begin{tabular}{|c|c|c|c|}
\hline & Everyday & Several times a week & I don't eat them \\
\hline Girls with proper body weight & $48,80 \%$ & $48,80 \%$ & $2,30 \%$ \\
\hline Boys with proper body weight & $60,0 \%$ & $37,10 \%$ & $2,90 \%$ \\
\hline Boys with excess body weight & $50,0 \%$ & $40,0 \%$ & $10,0 \%$ \\
\hline Girls with excess body weight & $58,0 \%$ & $41,60 \%$ & $0,0 \%$ \\
\hline Total & $54,0 \%$ & $43,0 \%$ & $3,0 \%$ \\
\hline
\end{tabular}

Due to the increasing trend among young people of eating „fast food” the respondents were asked whether they feed themselves in this way. It was shown that $78 \%$ of respondents consumed these products very rarely. Similar number of respondents who consumed these products every day (7\%) or several times a week (9\%) (Table 13).

The thirteenth question in the questionnaire concerned the family tendency towards obesity. Based on the analysis results it was indicated that adolescents who are overweight or obese pointed to the obese or overweight person in the family. This was indicated by $68.0 \%$ of the respondents answered with excess body weight, but up to $65.0 \%$ of all respondents did not indicate overweight or obesity in their family (Table 14).

It was shown that $80.0 \%$ of boys and $76.7 \%$ girls with normal body weight eat meals at home, and $9.1 \%$ of adolescents with abnormal body weight eat dinner-supper combinbed (Table 15).

Table 13. Frequency of eating products of " fast food" type-total researched according to gender and body weight

\begin{tabular}{|c|c|c|c|c|}
\hline & Everyday & Several times a week & Very rarely & I don't eat them \\
\hline Girls with proper body weight & $2,30 \%$ & $11,60 \%$ & $76,70 \%$ & $9,30 \%$ \\
\hline Boys with proper body weight & $11,40 \%$ & $0,0 \%$ & $85,70 \%$ & $29,0 \%$ \\
\hline Boys with excess body weight & $20,0 \%$ & $10,0 \%$ & $60,00 \%$ & $10,0 \%$ \\
\hline Girls with excess body weight & $0,0 \%$ & $25,0 \%$ & $75,00 \%$ & $0,0 \%$ \\
\hline Total & $7,0 \%$ & $9,0 \%$ & $78,0 \%$ & $6,0 \%$ \\
\hline
\end{tabular}

Table 14. Family occurance of excess body weight-total researched according to gender and body weight

\begin{tabular}{|c|c|c|}
\hline & $\begin{array}{c}\text { there is a person in the family with } \\
\text { excess body weight or obesity }\end{array}$ & $\begin{array}{c}\text { there is no person in the family with ex- } \\
\text { cess body weight or obesity }\end{array}$ \\
\hline Girls & $40,0 \%$ & $60,0 \%$ \\
\hline Boys & $29,0 \%$ & $71,0 \%$ \\
\hline Youth with excess body weight & $68,0 \%$ & $32,0 \%$ \\
\hline Total & $35,0 \%$ & $65,0 \%$ \\
\hline
\end{tabular}

Table 15. Ritual of eating meals by the youth-total researched according to gender and body weight

\begin{tabular}{|c|c|c|c|c|}
\hline & $\begin{array}{c}\text { Meals prepared } \\
\text { by parents }\end{array}$ & $\begin{array}{c}\text { I eat } \\
\text { at the counteen }\end{array}$ & $\begin{array}{c}\text { I buy take } \\
\text { away dinners }\end{array}$ & $\begin{array}{c}\text { I eat dinner-supper } \\
\text { combined }\end{array}$ \\
\hline Girls with proper body weight & $76,70 \%$ & $9,30 \%$ & $2,30 \%$ & $11,60 \%$ \\
\hline Girls with proper body weight & $80,0 \%$ & $5,7,0 \%$ & $0,0 \%$ & $14,30 \%$ \\
\hline Youth with excess body weight & $86,40 \%$ & $4,50 \%$ & $0,0 \%$ & $9,10 \%$ \\
\hline Total & $80,0 \%$ & $7,0 \%$ & $1,0 \%$ & $12,0 \%$ \\
\hline
\end{tabular}

It was found that $97.1 \%$ of boys with normal body weight consider physical activity to be important in life. A slightly smaller percentage of them were girls of normal weight (95.4\%). Percentage shares of recipients with normal body weight who did not have an opinion on this were similar. For $9.0 \%$ of adolescents with excess body weight physical activity was not significant in life. All participants were asked how much time per day they devoted to physical activity. It was shown that $62.9 \%$ of boys with normal weight and $44.2 \%$ of girls with normal body weight devoted to the activity 1-2 hours a day. It was shown that adolescents with excessive body weight more often exhibited physical activity during physical education classes. The time of „less than an hour” was less frequently pointed by boys of normal weight than girls, respectively (8.6\%, 25.6\%). It was shown that the question „how many times a week are you physically active outside of physical education classes”, $44.2 \%$ of girls of normal 
weight and $41.6 \%$ of boys with excessive body weight answered 2-3 times week. Daily physical activity was noted by $31.4 \%$ of boys of normal weight and $30 \%$ of girls with abnormal body weight. It was shown that $33.3 \%$ of boys and $10 \%$ girls with abnormal body weight did not take any physical activity, and $50 \%$ of girls with excess body weight were physically active once a week.

It was shown that $91.6 \%$ of boys with excessive body weight spent their free time at the computer, and $33.3 \%$ watched television. Only $10 \%$ of girls with abnormal body weight spent their free time actively. It was shown that $67.0 \%$ of girls of normal weight, „worked” at the computer, 51.10\% read books, and 32.0\% watched television. Among the boys of normal weight the predominant form of leisure was computer (65.7\%) and physical activity (57.1\%) (Table 16).

Table 16. Free time activities-total researched according to gender and body weight

\begin{tabular}{|c|c|c|c|c|c|c|c|}
\hline & $\begin{array}{c}\text { I watch } \\
\text { TV }\end{array}$ & Computer & I read & $\begin{array}{c}\text { I spend } \\
\text { active time }\end{array}$ & Walk & $\begin{array}{c}\text { Social } \\
\text { meetings }\end{array}$ & Other \\
\hline Girls with proper body weight & $32,50 \%$ & $67,40 \%$ & $51,10 \%$ & $27,90 \%$ & $39,50 \%$ & $81,40 \%$ & $1,0 \%$ \\
\hline Boys with proper body weight & $20,0 \%$ & $65,70 \%$ & $28,60 \%$ & $57,10 \%$ & $5,70 \%$ & $40,0 \%$ & $2,0 \%$ \\
\hline Boys with excess body weight & $30,0 \%$ & $70,0 \%$ & $20,0 \%$ & $10,0 \%$ & $20,0 \%$ & $60,0 \%$ & $0,0 \%$ \\
\hline Girls with excess body weight & 33,30 & $91,60 \%$ & $8,30 \%$ & $0,0 \%$ & $16,60 \%$ & $50,0 \%$ & $0,0 \%$ \\
\hline Total & $28,0 \%$ & $70,0 \%$ & $34,0 \%$ & $33,0 \%$ & $23,0 \%$ & $61,0 \%$ & $3,0 \%$ \\
\hline
\end{tabular}

It was shown that $35 \%$ of boys with excessive body weight and $40 \%$ of girls spent in front of the computer more than four hours a day. It was also shown that there were two identical groups of respondents (51.0\% each), which spent at the computer 1-2 hours a day. It was found that $59.3 \%$ of boys with abnormal body weight spent at the computer 3-4 hours a day.

The research results made it possible to show the most popular places visited by the students outside the classroom. Membership to Sports Club was indicated by $28.6 \%$ of boys and $6.9 \%$ of girls with normal body weight and only $9.10 \%$ with abnormal body weight. House of Culture was rarely pointed out by boys (2.9\%) with normal body weight, but more girls (16.3\%) than adolescents with abnormal body weight (13.6\%). Library was more frequently indicated by girls than boys with normal body weight, respectively $(34.9 \%, 14.3 \%)$. It was shown that $54.5 \%$ of adolescents with excess body weight did not use any form of extra-curricular activities.

It was shown that $59.1 \%$ of adolescents with abnormal body weight were dissatisfied with their operability, and $9.10 \%$ thought they were more physically fit than their peers. It was shown that boys with normal weight were more than twice happier with their physical fitness $(51.4 \%)$ than girls $(23.3 \%)$. It was also shown that up to $65.1 \%$ of girls with normal body weight were of the opinion that their efficiency was similar to that of their peers.

According to the researched boys of normal weight physical activity improves health and physique. It was shown that $18.2 \%$ of adolescents with excess body weight was of the opinion that physical activity allows to pleasantly spend time and according to $63.6 \%$ of the students physical activity improves condition.

The question 'How do you assess your figure?' was answered by $62.9 \%$ of boys and $44.2 \%$ girls with normal body weight and $8.3 \%$ of boys with excessive body weight that it was considered by them to be normal. It was shown that $90 \%$ of girls and $83.3 \%$ boys could see the need for losing weight, more frequently girls with normal body weight, than boys, respectively (46.5\%, 20\%). For the rest, the appearance of their own silhouette had no meaning or they had no opinion on the subject.

It was shown that adolescents with abnormal body weight, more often than those with normal body weight were of the opinion that being overweight or obese causes teasing from peers. Percentage shares of researched pupils with normal weight (34\%) who responded that there are no differences in the perception of people with excess body weight were identical.

\section{Discussion}

All over the world, a steady increase in the number of young people who are overweight and obese is observed. (Gawlik et al., 2009, Oblacińska et al., 2007). The report of the International Organization of Fighting Overweight and Obesity (IOTF - International Obesity Task Force) for the years 2007-2011 period shows that every fifth child in Europe has a problem with maintaining a healthy weight, and in Poland about $10 \%$ of the pediatric population has health problems due to obesity (Jarosz 2010). 
Preventive measures of overweight and obesity should be multidirectional, and according to previous studies, the children do not know or do not follow the rules of healthy lifestyle: healthy eating and physical activity. For these reasons, their health education needs to be conducted in such a way so that they understood how important this issue is (Smorczewska-Czupryńska et al., 2002).

Studies have shown that body weight in $43.0 \%$ of girls and $35.0 \%$ boys ranged between 5 and 85 percentiles, but overweight (11.3\%) was more frequent than obesity (7.5\%) among the girls. The reason for this may be the popularization of thinness among girls (Gałuszka, Gałuszka 2010). It is noted that a hallmark of rational nutrition is adequate quantity and regularity of meals (Kochan, Karaś 2011). The recommended 4-5 meals per day are consumed by $30.0 \%$ of respondents. This did not confirm the results of other authors (Pieszko-Klejnowska et al., 2007, Piórecka et al., 2007), as 4-5 meals a day were more often indicated by girls with excess body weight than boys. The study revealed the problem of the lack of first breakfast and second breakfast. The first breakfast was consumed more often by the boys (48.6\%) with normal body weight and as much as $30.0 \%$ of respondents did not eat a second breakfast. This is confirmed by the results of Pieszko-Klejnowska and other authors (Jeżewska-Zychowicz 2006 Jeżewska-Zychowicz 2003 Pieszko-Klejnowska et al., 2007, Suliga 2006). Pieszko-Klejnowska showed lack of breakfast among $48 \%$ of girls and 39\% boys in junior high schools in the Pomeranian province (Pieszko-Klejnowska et al., 2007). It is concluded that the psychophysical consequences of the lack of breakfast cause: distraction, lack of concentration, fatigue and apathy, and hunger that provokes aggressive behavior toward peers (Wojnarowska, Komosińska 2000).

Piórecka and other authors in their study demonstrated that fast food is a favorite form of snacks between meals among male high school students in Malopolska (Piórecka et al., 2007, Połom, Sińska 2003). Author's findings showed that $78 \%$ of respondents do not prefer this method of feeding. According to Czupryński et al consumers of fast food products are a group of people potentially exposed to the occurrence of diet-related diseases in the future (Smorczewska-Czupryńska et al., 2004). In our study, $42.9 \%$ of boys and $48.8 \%$ of girls of normal weight often snack between meals, which corresponds to reports Białokoz-Kalinowska. The author showed that $83.5 \%$ of students snacks sweets between meals (Białokoz-Kalinowska i in., 2000).

Results by Pieszko-Klejnowska and Zawadzka indicate that young people rarely eat vegetables and fruit. An example might be the youth from Pomeranian province where only 53.1\% consumed fruits and vegetables on a daily basis (Pieszko-Klejnowska et al., 2007, Zawadzka 1999). This was confirmed by author's elaboration, because $54.0 \%$ of the respondents consumed fruits and vegetables daily. Zawadzka found that the youth draws energy from the sweet carbonated beverages, and the issue of consumption of cola drinks is a serious problem in the whole world (Zawadzka, 1999). It was shown that the sweet carbonated beverages in a daily diet were indicated by $34 \%$ of respondents.

According to Stankiewicz and others, the young person spends passively until 3.5 hours per day using a variety of media (Krebs, Primak 2012, Mazur 2011, Plewa, Markiewicz 2006). It was shown that up to 91.6\% of boys with excessive body weight spend their free time at the computer, and only $10 \%$ of girls with abnormal body weight spend their free time actively.

\section{Conclusions}

Based on the results the following conclusions were drawn:

1. Obesity occurs in $7.50 \%$ of girls and $8.50 \%$ of boys of middle school in Lubartów.

2. The youth knows the principles of nutrition, but not always selects healthy products, eats inappropriately, snacks between meals.

3. Middle school students rarely eat vegetables, fruits and dairy products.

4. Hereditary phenomenon of obesity has been observed in subjects with abnormal body weight.

5. The youth is not physically active, their free time is spent in a passive way.

6. Overweight / obesity determines a negative social assessment and the assessment by peers.

\section{References:}

1. Białokoz-Kalinowska I., Zagórecka E., Piotrowska-Jastrzębska J. (2000), Ocena sposobu żywienia dzieci w wieku szkolnym z terenu miasta i okolic Białegostoku. Pediatria Polska, 75, 8, s. 643-646.

2. Dolżał-Ołtarzewska K., Starzyk J. (2005), Otyłość, W: J. Pietrzyk (red.), Wybrane zagadnienia z pediatrii. tom IV, Wydawnictwo Uniwersytetu Jagiellońskiego. Kraków, s. 333-341. 
3. Gałuszka G., Gałuszka R. (2010), Otyłość u dzieci jako problem psychospołeczny, W: M. Juszczyk (red.), Wybrane zagadnienia z edukacji zdrowotnej. Wyższa Szkoła Ekonomii i Prawa w Kielcach, Kielce, s. 399-407.

4. Gawlik A., Zachurzok-Buczyńska A., Małecka-Tendera E. (2009), Powikłania otyłości u dzieci i młodzieży. Endokrynologia, Otyłość i Zaburzenia Przemiany Materii, tom 5, nr 1 s. 19-27.

5. Jarosz M. (2010), Działania prowadzone w Polsce na rzecz zwalczania nadwagi i otyłości. Endokrynologia Otyłość i Zaburzenia Przemiany Materii, tom6, nr 1. s. 49-53.

6. Jeżewska-Zychowicz M. (2006), Wpływ wybranych cech indywidualnych i środowiskowych na zachowania żywieniowe młodzieży. Wydawnictwo SGGW, Warszawa s. 127-154.

7. Jeżewska-Zychowicz M. (2003), Wpływ środowiska rodzinnego i szkolnego na częstotliwość spożywania posiłków przez młodzież w wieku 13-15 lat na przykładzie środowiska warszawskiego. Żywienie Człowieka i Metabolizm, 30,1, s. 93-97.

8. Jodłowska M., Oblacińska A., Woynarowska B. (2007), Test przesiewowy do wykrywania zaburzeń w rozwoju fizycznym u dzieci i młodzieży w wieku szkolnym. Instytut Matki i Dziecka, Warszawa, s. 9-14.

9. Kochman D., Karaś H. (2011), Przyczyny i następstwa otyłości prostej u dzieci W: M. Wojciechowska (red.), Wyzwania współczesnej pediatrii. Akademia Humanistyczno -Ekonomiczna w Łodzi, Łódź, s. 201-229.

10. Krajewska-Siuda E., Nowak A., Matusik P., Wypych-Ślusarska A., Małecka-Tendera E. (2009), Opinie młodzieży na temat otyłości w zależności od ich własnej masy ciała. Endokrynologia, Otyłość i Zaburzenia Przemiany Materii, tom 5, nr 1, s.7-11.

11. Krebs N., Primak L. (2012), Żywienie dzieci i zaburzenia odżywiania, W: A. Milanowski (red.), Pediatria t.1. Elsevier Urban \&Partner, Wrocław, s. 109-128.

12. Mazur A. (2011), Epidemiologia nadwagi i otyłości u dzieci na świecie, w Europie i w Polsce. Wydawnictwo Uniwersytetu Rzeszowskiego, Rzeszów, 2, s.158-163

13. Oblacińska A., Jodłowska M., Tabak I. (2006), Epidemiologia otyłości u młodzieży w okresie pokwitania w Polsce W: A. Oblacińska, I. Tabak (red.), Jak pomóc otyłemu nastolatkowi - rola pielęgniarek szkolnych i nauczycieli wychowania fizycznego we wspieraniu uczniów i ich rodziców. Instytut Matki i Dziecka, Warszawa, s.11-84.

14. Oblacińska A., Jodłowska M., Tabak I. (2007), Ocena częstości występowania nadwagi i otyłości u młodzieży $w$ wieku 13-15 lat w Polsce przy zastosowaniu różnych narzędzi badawczych. Przegląd Epidemiologiczny, 61, s. 585-592.

15. Pieszko-Klejnowska M., Stankiewicz M., Niedoszytko M., Kozanecka I., Łysiak-Szydłowska W. (2007), Ocena sposobu odżywiania się gimnazjalnej młodzieży zamieszkującej wieś i miasto. Pediatria Współczesna Żywienie Dzieci, 9/1, s. 59-62

16. Piórecka B., Jagielski P., Wójcik K., Żwirska J., Schlegel-Zawadzka M. (2007), Zachowania żywieniowe młodzieży gimnazjalnej w Małopolsce. Żywienie Człowieka Metabolizm, 34, 1⁄2, s. 620-628.

17. Plewa M., Markiewicz A. (2006), Aktywność fizyczna w profilaktyce i leczeniu otyłości. Endokrynologia Otyłość i Zaburzenia Przemiany Materii. tom 2, nr 1, s. 30-37.

18. Połom A., Sińska B. (2003), Postawy młodych konsumentów wobec produktów typu Fast food. Bromatologia i Chemia toksykologiczna, supl. 36, s. 167-172.

19. Smorczewska-Czupryńska B., Ustynowicz-Farbiszewska J., Karczewski J. (2004), Diet of Junior High School Students - Energy Value and Basic Nutritional Components In the Respective Seasons of the Year. Polish Journal of Enviromental Studies, supl II, 13, s.508-511.

20. Smorczewska-Czupryńska B., Ustynowicz-Farbiszewska J., Karczewski J. (2002), Jakościowa i ilościowa ocena żywienia młodzieży gimnazjalnej z Białegostoku i okolic. Wiadomości Lekarskie, 55, supl. 1, 1: s. 550-555.

21. Suliga E. (2006), Częstotliwość spożycia i wartość energetyczna śniadań wśród dzieci i młodzieży w wieku szkolnym. Roczniki PZH, 57, 1, s. 73-80.

22. Wojnarowska B., Komosińska K. (2000), Samoocena zdrowia i obraz własnego ciała u młodzieży szkolnej w Polsce. Pediatria Polska, 75, s. 25-34.

23. Zawadzka B. (1999), Zachowania zdrowotne młodzieży wyzwaniem dla zreformowanej edukacji. Wychowanie Fizyczne i Sport, 46, 5, s. 181-186

Submitted: 28.01.2014

Accepted: 05.02.2014 